\title{
LETTERS
}

\section{Increased xanthine oxidase activity in idiopathic pulmonary arterial hypertension}

\section{To the Editors:}

Oxidative stress may play a role in the pathogenesis of idiopathic pulmonary arterial hypertension (IPAH) [1-4]. A major contributor to oxidative stress is the endothelium-bound enzyme xanthine oxidase $(\mathrm{XO})$, which is involved in the generation of superoxide anions and peroxynitrite [5]. These reactive oxygen species have been implicated in endothelial dysfunction and vascular damage [5]. In vivo, $\mathrm{XO}$ is bound to the surface of endothelial cells by glycosaminoglycans and can be released into plasma by heparin bolus injection [6]. XO activity has not been assessed in patients with IPAH, but increased activity of this enzyme is suggested by hyperuricaemia, a common finding in patients with IPAH [7].

In the present study, activity of endothelium-releasable XO was measured in the plasma of 31 treatment-naive patients with IPAH (nine male, 22 female, mean pulmonary arterial pressure $51 \pm 13 \mathrm{mmHg}$ ) and six healthy controls. In the IPAH patients, the samples were obtained during right heart catheterisation to compare $\mathrm{XO}$ activity and haemodynamics. $\mathrm{XO}$ activity was determined by using electron spin resonance spectroscopy (ESR), as described elsewhere [6]. XO activity was measured at baseline and 1, 3, 5, 7, 10 and 20 min after intravenous administration of heparin (5,000 IU), and depicted as area under the curve with the values shown as arbitrary units (AU). The present study was approved by the local institutional review board and all patients gave written informed consent.

It was found that $\mathrm{XO}$ activity was increased in IPAH patients compared with healthy controls $(5,201 \pm 2,836$ AU versus 2,424 $\pm 1,419$ AU, $p=0.026$, Mann-Whitney U-test). There was no significant correlation between $\mathrm{XO}$ activity and haemodynamic parameters, such as right atrial pressure, mean pulmonary arterial pressure, cardiac output, pulmonary vascular resistance, or mixed-venous oxygen saturation, respectively. There was also no correlation between XO activity and plasma uric acid levels. In three patients, however, $\mathrm{XO}$ activity was measured again 3 months after introduction of treatment with bosentan, an endothelin receptor antagonist, and was found to be markedly lower than prior to therapy (3,052 \pm 747 AU versus 8,438 $\pm 5,695$ AU).

These preliminary data suggest that $\mathrm{XO}$ activity is elevated in patients with IPAH, which may be a contributing factor to endothelial dysfunction and vascular damage in this disease. Further investigations need to determine whether targeted treatment of pulmonary arterial hypertension with endothelin receptor antagonists [8], or other compounds, such as phospodiesterase-5 inhibitors [9] or prostanoids [10], may improve $\mathrm{XO}$ activity and endothelial function in these patients.

\author{
S. Spiekermann*, K. Schenk ${ }^{\#}$ and M.M. Hoeper ${ }^{\#}$ \\ Depts of *Cardiology and "Respiratory Medicine, Hannover \\ Medical School, Hannover, Germany.
}

Correspondence: M.M. Hoeper, Hannover Medical School, Dept of Respiratory Medicine, Carl-Neuberg-Str. 1, 30625 Hannover, Germany. E-mail: hoeper.marius@mh-hannover.de

Statement of Interest: A statement of interest for M.M. Hoeper can be found at www.erj.ersjournals.com/misc/statements.dtl

\section{REFERENCES}

1 Jankov RP, Kantores C, Pan J, et al. Contribution of xanthine oxidase-derived superoxide to chronic hypoxic pulmonary hypertension in neonatal rats. Am J Physiol Lung Cell Mol Physiol 2008; 294: L233-L245.

2 DeMarco VG, Habibi J, Whaley-Connell AT, et al. Oxidative stress contributes to pulmonary hypertension in the transgenic (mRen2)27 rat. Am J Physiol Heart Circ Physiol 2008; 294: H2659$\mathrm{H} 2668$.

3 Nozik-Grayck E, Stenmark KR. Role of reactive oxygen species in chronic hypoxia-induced pulmonary hypertension and vascular remodeling. Adv Exp Med Biol 2007; 618: 101-112.

4 Sommer N, Dietrich A, Schermuly RT, et al. Regulation of hypoxic pulmonary vasoconstriction: basic mechanisms. Eur Respir J 2008; 32: 1639-1651.

5 Heitzer T, Schlinzig T, Krohn K, et al. Endothelial dysfunction, oxidative stress, and risk of cardiovascular events in patients with coronary artery disease. Circulation 2001; 104: 2673-2678.

6 Spiekermann S, Landmesser U, Dikalov S, et al. Electron spin resonance characterization of vascular xanthine and $\mathrm{NAD}(\mathrm{P}) \mathrm{H}$ oxidase activity in patients with coronary artery disease: relation to endothelium-dependent vasodilation. Circulation 2003; 107: 1383-1389.

7 Warwick G, Thomas PS, Yates DH. Biomarkers in pulmonary hypertension. Eur Respir J 2008; 32: 503-512.

8 Dupuis J, Hoeper MM. Endothelin receptor antagonists in pulmonary arterial hypertension. Eur Respir J 2008; 31: 407-414.

9 Wilkins MR, Wharton J, Grimminger F, et al. Phosphodiesterase inhibitors for the treatment of pulmonary hypertension. Eur Respir J 2008; 32: 198-209.

10 Olschewski H, Gomberg-Maitland M. Prostacyclin therapies for the treatment of pulmonary arterial hypertension. Eur Respir J 2008; 31: 801-901. 